\title{
Implementing Lean Management in the Romanian Industry
}

\author{
Paul Marinescu ${ }^{1}$, Sorin George Toma ${ }^{2}$ \\ 1 University of Bucharest, Faculty of Administration and Business, \\ 4-12 Regina Elisabeta, Bucharest, Romania \\ WWW home page:http://www.unibuc.ro/ro/fac_fad.ro \\ 2 Academy of Economic Studies Bucharest, Faculty of Commerce, \\ 13-15 Mihai Eminescu, Bucharest, Romania \\ WWW home page: http://www.comert.ase.ro
}

\begin{abstract}
Category of paper - Research paper combined with a case study

Purpose - To demonstrate that lean management could be successfully applied in an enterprise from an Eastern European country like Romania. To propose solutions in order to improve the current management practices in the Romanian industry and to increase productivity in order to deal with global competition. To implement the customer-supplier logic within a Romanian manufacturing enterprise.

Design/methodology/approach - The main objectives of the paper were achieved by using quantitative and qualitative research methods. A survey, based on a questionnaire applied to the firm's employees, was conducted and the work processes during a product cycle were observed by the two authors. Focus-groups were also organized within the Romanian enterprise.

Findings - Findings are related to the business environment and economical changes in Romania. Due to the implementation of lean management in the Romanian enterprise, waste decreased in a significant manner, work productivity increased and work area decreased. Also, by using lean production and management, emphasis is put on inter-functional effectiveness, process efficiency and system flexibility. Training (for instance " $5 \mathrm{~S}$ " training) and team work play a key role in implementing a customer-supplier logic (or internal client or customer-in) within the Romanian enterprise.
\end{abstract}

Research limitations - There are little statistical methods applied in the Romanian industry. That is why future research should focus on the performance measurement and the indicators used in the management of the processes in a manufacturing enterprise.

Practical implications - Romanian government, private and public enterprises could use the findings in order to rethink some of theirs management strategies and practices. Changes should be made within manufacturing enterprises in order to gain a flexible and organizational structure.

Originality/value - The paper shows that the lean paradigm leads to a management-byprocess organization. On the other hand, the paper demonstrates that lean management could be successfully applied in a Romanian manufacturing enterprise. Suggestions are made

Please use the following format when citing this chapter:

Marinescu, P. and Toma, S.G., 2008, in IFIP International Federation for Information Processing, Volume 257, Lean Business Systems and Beyond, Tomasz Koch, ed.; (Boston: Springer), pp. 269-276. 
regarding the solutions needed for improving the current managerial practices in the Romanian industry.

Keywords Lean thinking, lean manufacturing

\section{Introduction}

Originated at Toyota, the principles of lean management are applied in today's companies around the world because of their positive impact on company performance. Lean management shows a way to obtain more products with fewer resources while providing customers exactly what they want. The key factor behind the development of lean management is the elimination of waste (muda in Japanese). In order to deal with global competition, companies should adopt the lean paradigm, a flexible, adaptive and responsive paradigm.

The purpose of this paper is to demonstrate that lean management could be successfully applied in any Romanian manufacturing enterprise. The case study presented as an example is TOPEX, one of the leading Romanian manufacturers of communications solutions, which has introduced lean production in its plant. Changes required by lean production lead to a management-by-process organization. This assertion is based on a study of how TOPEX obtained outstanding performances through implementing lean management principles. The main objectives of the paper were achieved by using both quantitative and qualitative research methods. Finally, the authors made several suggestions regarding some possible solutions for improving the current managerial practices in the Romanian industry.

\section{From lean manufacturing to lean management and lean thinking}

The post-World War era brought the first pioneers of lean manufacturing. In Japan, a country with few natural resources, E. Toyoda, T. Ohno and S. Shingo created and implemented the Toyota Production System [5]. Focused on the elimination of all non-manufacturing wastes (for example, inventory, quality defects, transportation), the system established and developed a lean manufacturing philosophy in response to the poor use of human, financial, and material resources. Lean thinking became the generic term to describe the universal application of the lean manufacturing philosophy.

The Japanese lean manufacturing emphasizes the importance of small batch sizes and just-in-time (JIT) delivery. By contrast, the traditional American production system puts on the first place the batch-and-queue concept. As Emiliani recently pointed out, the level of American awareness of lean manufacturing remained low until the 1980's. Twenty years ago, Mather [3] anticipated the emergence of lean manufacturing in USA. Based on the JIT production method, he stressed on the importance of producing the right products for the right markets at the right time and traced six ways to prepare the future factory (box 1). 
Box 1

In 1988, Mather asserted that there are six ways to prepare for a factory with a future:

1. "simplify the environment to cope better with complexity;

2. institute simpler, more effective control systems;

3. spend more time on future if you want to have a future;

4. give your people the right training now- before it's too late;

5. redefine your organizational structure to make smart decisions and get fast results;

6. pave the way for important changes in responsibility and accountability".

Source: [3, pp. 216-220]

As a multi-dimensional approach, lean production encompasses "a wide variety of management practices, including, JIT, quality systems, work teams, cellular manufacturing, supplier management, etc. in an integrated system" [6]. Lean management is designed to identify and eliminate all forms of waste in the process of producing goods and services. Many companies from different countries and various fields of activity obtain significant gains by implementing the lean management principles.

Lean management and lean thinking are strongly linked. According to the lean thinking, the business has to be managed starting from the customer definition of value. The customer is the only one who determines whether or not a product/service satisfies his/her needs. In the 1990's, Womack [7] presented the following key concepts of lean thinking:

- Value. Value represents the product/service's capability provided to a customer at the right time, at an appropriate price.

- Value stream. Value stream comprises all activities required to bring a product/service from order to the hands of the customer.

- Flow. All the activities needed to the completion of a product/service have to be organized in a continuous flow.

- Pull. The pull system enables the production of what is really needed, only when the customer (internal or external) requests it.

- Perfection. In order to strive for perfection, companies are aware that the elimination of all forms of waste is endless. In other words, there will always be wastes to be eliminated in a company.

Although these lean concepts have been predominantly applied in the manufacturing enterprises, during the last decades, they have proven to be universally successful at improving companies performance.

\section{Implementing lean management in Romania. Case study}

Lean management is rather a new concept in Romania. In 2003, the University of Gent (Belgium) and the Romanian National Council of Private SMEs started a twoyear project, called "Enhancement of the productivity in the productive SMEs by 
applying the lean manufacturing method". In 2005, some of the participants at the project created the "Association of Romanian Lean Experts" [8], in order to continue the know-how transfer in the field of lean production. TOPEX has been one of the ten Romanian SMEs selected to implement lean manufacturing and management.

Founded in 1990 by ten engineers experienced in telecommunications, TOPEX is a private Romanian company [9]. In the last fifteen years, TOPEX has become one of the most important Romanian manufacturers of communications solutions for small to large companies as well as for telecommunications operators and service providers. Partners of TOPEX are Siemens, Cisco System, Alcatel and Telemobil. Its main activity is directed to the design and production of telecommunication equipment, but TOPEX also considered the training and after-sale service as an integral part of the solutions it provides. The company has 122 employees and 8 departments (Production, Marketing, Sales, Finance, Service, Human Resources, Quality Assurance, and Research \& Development). Most employees are part of the Production Department (29 employees) and of the R\&D Department (29 employees). All products are designed within the R\&D Department. More than $70 \%$ of the output is exported in 34 countries from Europe (Germany, France, Spain, United Kingdom, Italy etc.), Asia, Africa and USA through a wide network of local and international distributors.

The Production Department is structured as follows: Planting Workshop (11 employees), Control Workshop (12 employees), Mechanical Workshop (4 employees), Packaging ( 2 employees). In the production activity (Figure 1$)$, the main unit is the card. The card is made of electronic components, imported from Europe and USA, and is assembled on a Printed Circuit Board (PCB), imported from Asia. Within this department, the employees use:

- One ASSEMBLEON “pick and place" robot (Holland), making equipments according to the European Directives on the environmental protection and consumer safety, purchased in 2006.

- $\quad$ One FRITSCH robot (Germany), purchased in 2000.

- $\quad$ One SMD gluing stove with 5 areas, VIP 70 (USA), purchased in 2006.

For the purpose of using the robots, the employees have been sent to training at the producers of such.

Three TOPEX engineers participated in lean manufacturing and management trainings. Since 2005, they have successfully implemented the lean management principles at TOPEX. According to the lean thinking, the TOPEX slogan became: "To serve the internal customer as if it was the final one".

In order to understand and apply lean manufacturing, all employees were trained by the three engineers (main themes were: $5 \mathrm{~S}$, total productive maintenance, Kaizen, lean management etc.). The implementation of lean manufacturing and management started with an analysis of the company's results and of the customers' needs. Grounded on such analysis and on the role of the cards in each of the equipments designed, the management established the following objectives:

- The increase of the work productivity by $30 \%$.

- The decrease of lead time by $40 \%$.

- The decrease of the production time by $20 \%$. 


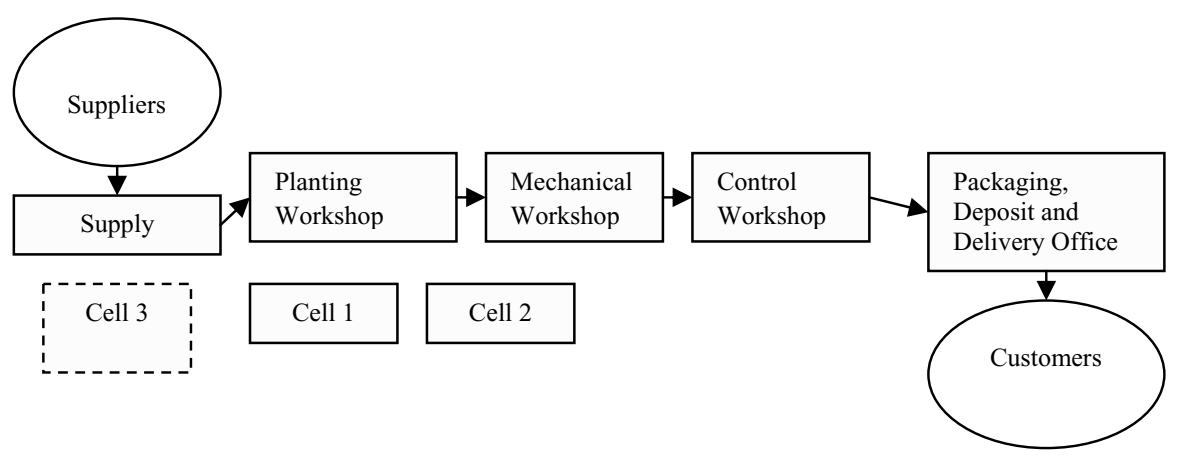

Fig. 1. The production flow at TOPEX

Changes required by lean production lead to a management-by-process organization at TOPEX. According to lean manufacturing, 2 work cells have been designed in the Production Department, each of them with 2 employees (Figure 2). The time needed in order to implement a work cell was of $1 \frac{1}{2}$ hour. Proceedings and working instructions were created for the each work cell and for each employee.

Cell 1 in the Planting Workshop

First employee:

- Placing labels

- $\quad$ Scanning the card series

- Updating Excel file with specific information

Second employee:

- Cut pins

- Cards movement
Cell 2 in the Control Workshop First employee:

- Assembling card front side

- Assembling card modules

- Applying labels

- Packing

Second employee:

- Card testing

Fig. 2. The two work cells of the Production Department at TOPEX

Automatically, the working tasks within a cell have been balanced, and by this the inactive periods were eliminated. Even if the tasks are modified, each cell member is subordinated to only one workshop supervisor. Each employee performs quality control in his/her own workplace. The damaged parts are placed into distinct boxes and then are re-tested individually by the employees.

TOPEX obtained outstanding performances through implementing lean management principles (Table 1). Regarding the VOXELL equipments produced, the results were quite impressive: productivity and efficiency were way up and the employees became enthusiastic and eager to learn more. 
Table 1. The results obtained before and after the implementation of lean manufacturing and management at TOPEX

\begin{tabular}{|l|l|l|l|}
\hline Item & Criteria & \multicolumn{2}{|c|}{ Results } \\
\cline { 3 - 4 } & & Before implementation & After implementation \\
\hline 1. & Card testing & 22 cards/day & 32 cards/day \\
\hline 2. & Production time & $315 \mathrm{~min}$ & $75 \mathrm{~min}$ \\
\hline 3. & Testing duration & $20 \mathrm{~min} /$ card & $12 \mathrm{~min} /$ card \\
\hline 4. & Stock quantity & 321 cards/day & 215 cards/day \\
\hline 5. & $\begin{array}{l}\text { VOXELL } \\
\text { production }\end{array}$ & $150 /$ week & $400 /$ week \\
\hline 6. & Lead time & 13 days & 6.7 days \\
\hline
\end{tabular}

A total time economy of approximately 28,000 minutes per year was obtained or, in other words, an additional production of 3,500 cards each year. The work productivity increased with up to $45 \%$. In the future, another work cell will appear.

The authors carried out a research at TOPEX. The research was grounded on:

$>$ quantitative methods (questionnaire);

$>$ qualitative methods (focus-group).

The questionnaire was applied in the Production Department, on 27 employees. The questionnaire comprises 21 questions, referring to: the need of implementing lean manufacturing and management, the means in which it was implemented, the results obtained after the implementation, the modality of noticing the manufacturing errors, the type of organizational culture in the company, the leadership style, the decision making process, the evaluation of the implementation (stocks, work processes, maintenance, relationship with the suppliers and customers, quality, planning and control of the processes, visual management).

Throughout several visits at TOPEX, the authors identified the production processes, the main flows and the intra and inter departmental relations, by means of direct observation. Also, the authors set out two focus-groups with 5 employees and 3 managers from the Production and Quality Assurance Departments. The focusgroups were aimed towards the following themes: the need of applying lean manufacturing and implementing lean management principles, the role of lean trainings and working in teams, the importance of the customer-supplier logic consequent to the implementation of lean manufacturing, the employee's motivation.

The findings of our research are the following:

- All TOPEX employees are aware of the importance of the implementation of lean manufacturing and management. The employees' involvement has significantly increased.

- The implementation of lean management has lead to a better correlation between production and market demand, to the establishment of flexible work cells, to the reduction of the manufacturing errors and of the waiting times between the production phases, to job enrichment and improvement of the working conditions, to an increase of the processes efficiency and of the inter-functional effectiveness. 
- The company's performances after the implementation of lean are manifested in the increase of the turnover and of the work productivity, and of the decrease of costs.

- The leadership style combines consultation and participation.

- The organizational culture is characterized by team work and discipline.

- The employees are motivated by the diversity of the tasks, by professional development ( $5 \mathrm{~S}$ training, mentoring) and by means of wages and bonuses.

- The implementation of a lean strategy is necessary for the purpose of eliminating waste.

- Team work and trainings play a key role in order to implement are a customer-supplier logic (or internal client or customer-in) within the company.

- The complexity of the customers' activities (fix and mobile telephony, Internet providers, aeronautics, post services etc) has imposed a rapid adaptation to their needs, by means of flexible production.

- Only $40 \%$ of the production process is statistical controlled and $35 \%$ of the production flow is realized without intermediary stocks.

- The contracts are concluded with the suppliers for an average duration of 20 months because $30 \%$ of them have implemented total quality management systems.

From the research it results that the implementation of lean in all the phases of the production process is needed. TOPEX has evolved to a management-by-process company. In the near future, the application of lean will continue at TOPEX in relation with the suppliers for the purpose of reducing the raw materials and materials stocks.

\section{Conclusions}

The aim of this paper is to contribute to the subject of lean management. The case study described demonstrates that lean management could be successfully applied in any Romanian manufacturing enterprise. Once rare outside the factory, lean tools are increasingly applied in the private and public enterprises from different fields of activity. In this respect, Romanian government, private and public enterprises could use the findings of our paper in order to rethink some of theirs management strategies and practices.

In Romania, lean manufacturing and management has been implemented in a relatively small number of companies and that is why campaigns should be initiated in order to promote the advantages of lean. The participation of specialists from countries with tradition (Japan, USA etc) in implementing lean management in the Romanian industry should contribute to the development of a national network of lean experts and organizations.

Thoughtfully implemented in Romania, lean will lead to excellence and to a collaborative and creative environment. In a globalized world, Romanian companies should understand that lean improvements give stakeholders what they 
need, and managers the possibility to keep their business running side by side with the competitors.

\section{References}

1. Arnheiter, E. D. and Maleyeff, J., The integration of lean management and Six Sigma, The TQM Magazine, Vol. 17 No. 1, 2005, pp. 5-18.

2. Emiliani, M. L., Origins of lean management in America. The role of Connecticut businesses, Journal of Management History, Vol. 12 No.2, 2006, pp. 1678-184.

3. Mather, H., Competitive Manufacturing, Prentice Hall, Englewood Cliffs, New Jersey, 1988.

4. Jones, D. T., Building a Lean Management System, Production Systems Conference, Stuttgart, 14 June 2004, www.leanuk.org.

5. Ohno, T., Toyota Production System, Productivity Press, Portland, OR, 1988

6. Shah, R. and Ward, P. T., Lean manufacturing: context, practice bundles, and performance, Journal of Operations Management, 21 (2003), pp.129-149.

7. Womack, J. and Jones, D. T., Lean Thinking, Simon\&Schuster, New York, 1996.

8. The Association of Romanian Lean Experts, www.lean.ro.

9. TOPEX, www.topex.ro. 